Images in...

\title{
Chronic HIV-1 infection mimicking splenic malignant lymphoma on F-18 FDG-PET/CT
}

\author{
Florent Valour, ${ }^{1,2,3}$ Agathe Sénéchal, ${ }^{1,2}$ Christian Chidiac, ${ }^{1,2,3}$ Tristan Ferry 1,2,3 \\ 1Department of Infectious and Tropical Diseases, Hospices Civils de Lyon, Lyon, France; \\ 2Université Claude Bernard Lyon 1, Lyon, France: \\ 3INSERM U851, Lyon, France
}

Correspondence to Dr Tristan Ferry, tristan.ferry@univ-lyon1.fr

\section{DESCRIPTION}

A 49-year-old man with a general deterioration since 6 months was admitted for acute febrile purpura with pulmonary symptoms. Pancytopenia (32 000 platelets $/ \mathrm{mm}^{3}$ ), elevated lactate deshydrogenase, liver enzymes, ferritin and triglyceride levels were found. HIV-1 infection (viral load, $1.8 \times 10^{6}$ copies $/ \mathrm{ml}$; CD4 cell count, 185 cells $/ \mu \mathrm{l}$ ) and Pneumocystis jirovecii pneumonia were diagnosed. As thrombotic thrombocytopenic purpura and haemophagocytic syndrome were suspected, intravenous immunoglobulins were administrated. Transient Epstein-Barr virus and cytomegalovirus reactivations were recorded, without evidence for organ damage. Human herpesvirus type 8 PCR was not performed. Fluorodeoxyglucose positron emission tomography (FDG-PET)/CT disclosed hypermetabolic lymph nodes (standardised uptake value (SUV) $\max , 2.2$ to 5.2) with an increased metabolic activity of the bone narrow, the spleen, the liver (SUVmax, 2.6, 3.6 and 2.1, respectively) and the colonic omentum, strongly evocative of malignant lymphoma (figure 1A). Two bone

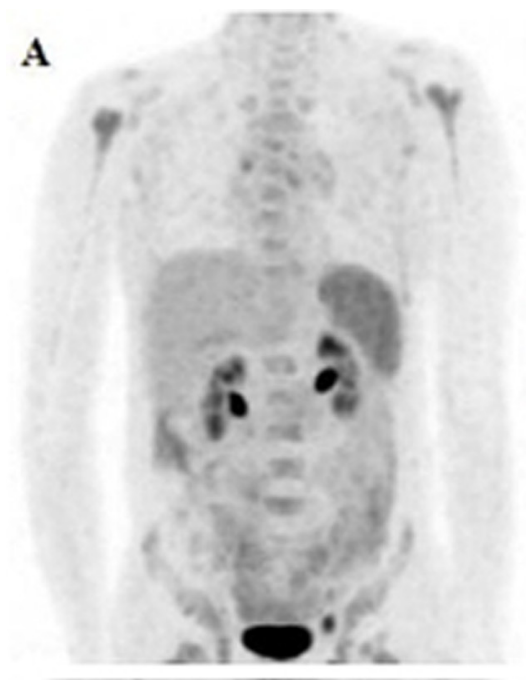

B

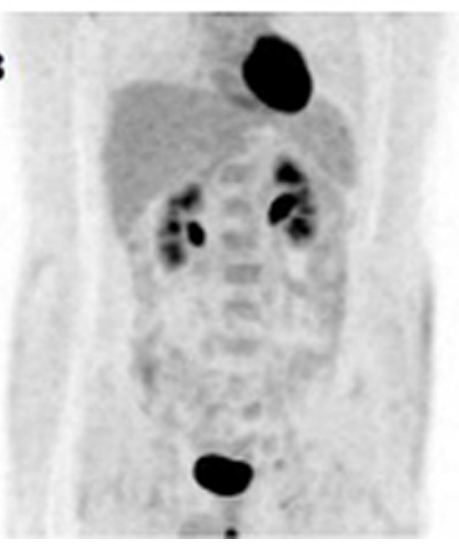

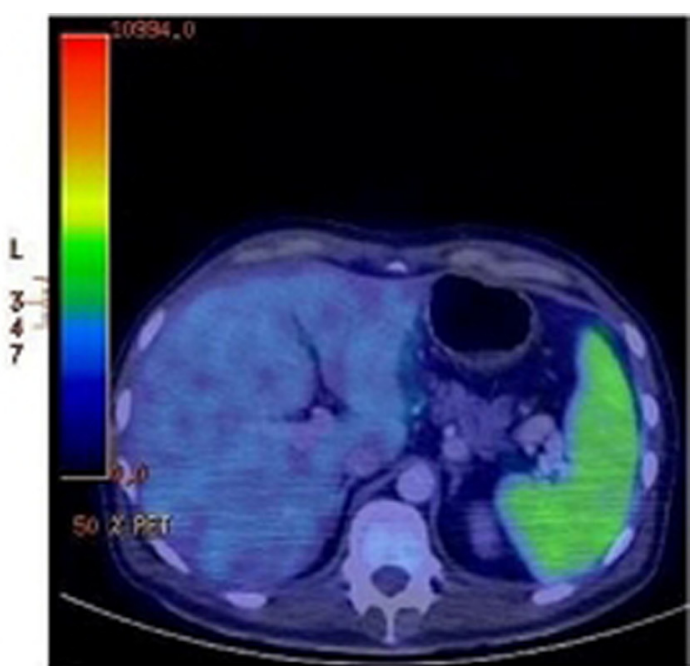

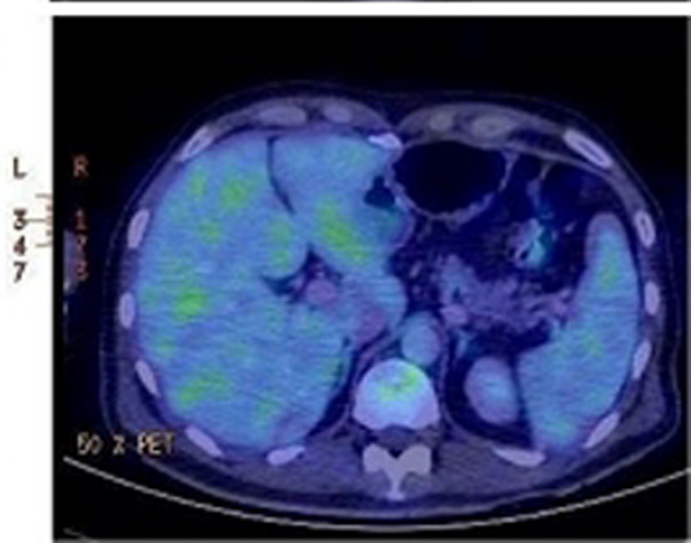

Figure 118 FDG PET/CT showing a hypermetabolic activity of the spleen evocative of a malignant lymphoma before (A) and after (B) the introduction of highly active antiretroviral therapy. 


\section{BMJ Case Reports}

narrow and three node biopsies found non-specific lymphocytic activation, only. Six months after the introduction of highly active antiretroviral therapy, the CD4 cell count reached $571 / \mathrm{mm}^{3}$, the viral load became undetectable and all pathologic findings disappeared, including abnormal metabolic activities on FDG-PET/CT (figure 1B). During HIV infection, activated lymphocytes increase their glucose utilisation and consequently the ${ }^{18} \mathrm{~F}-\mathrm{FDG}$ uptake of lymphoid tissues. ${ }^{18} \mathrm{~F}-\mathrm{FDG}$ uptake highly correlated with viral load and is mainly located in mesenteric and ileocecal areas during late disease. ${ }^{1}$ Splenic ${ }^{18} \mathrm{~F}$-FDG uptake seems to be less frequent in chronic HIV infection in comparison with other chronic viral infections, and mainly suggests HIV-associated lymphoma. ${ }^{1-3}$ This report highlights the potential for viral infections such as chronic HIV-1 infection, to mimic a malignant lymphoma on FDG-PET/CT.

Acknowledgements The authors acknowledge Dr Isabelle Morelec who performed the two F-18 FDG-PET/CT.

Competing interests None.

Patient consent Obtained.

\section{REFERENCES}

1. Iyengar S, Chin B, Margolick JB, et al. Anatomical loci of HIV-associated immune activation and association with viraemia. Lancet 2003;362:945-50

2. Banzo J, Ubieto MA, Prats E, et al. [18F-FDG PET-CT in cytomegalovirusinduced mononucleosis]. Rev Esp Med Nucl 2010;29:304-7.

3. Thomas DL, Syrbu S, Graham MM. Epstein-Barr virus mimicking lymphoma on FDG-PET/CT. Clin Nucl Med 2009;34:891-3.

This pdf has been created automatically from the final edited text and images.

Copyright 2012 BMJ Publishing Group. All rights reserved. For permission to reuse any of this content visit http://group.bmj.com/group/rights-licensing/permissions.

BMJ Case Report Fellows may re-use this article for personal use and teaching without any further permission.

Please cite this article as follows (you will need to access the article online to obtain the date of publication).

Valour F, Sénéchal A, Chidiac C, Ferry T. Chronic HIV-1 infection mimicking splenic malignant lymphoma on F-18 FDG-PET/CT. BMJ Case Reports 2012;10.1136/bcr.11.2011.5195, Published XXX

Become a Fellow of BMJ Case Reports today and you can:

- Submit as many cases as you like

- Enjoy fast sympathetic peer review and rapid publication of accepted articles

- Access all the published articles

- Re-use any of the published material for personal use and teaching without further permission

For information on Institutional Fellowships contact consortiasales@bmjgroup.com

Visit casereports.bmj.com for more articles like this and to become a Fellow 